\title{
The Composition and Physical Properties of Some Clays of Cross River State, Nigeria

\author{
L. E. Attah (PhD)
}

\section{Abstract}

Clay deposits collected from various locations in Cross River State, Nigeria were studied to determine their physical, compositional and firing characteristics in order to evaluate them for industrial uses. The samples were pulverized, sieved, digested with mineral acids and characterized. Results showed that the clays are mainly kaolinitic with only occasional illite, and quartz as the main subsidiary non-clay mineral. The high plasticity index of the clays corresponds to the more transported clays of the tertiary- to -recent environment. The percentage of linear shrinkage varied from $11-16 \%$ with the lowest shrinkage (11\%), having the coarsest features. Silica $\left(\mathrm{SiO}_{2}\right)$ content of the clays ranged from $47-70 \%$ while the alumina $\left(\mathrm{Al}_{2} \mathrm{O}_{3}\right)$ content which varied from $6-35 \%$ was lower than the theoretical value of kaolinite $(39.5 \%)$, with high iron $\left(\mathrm{Fe}_{2} \mathrm{O}_{3}\right)$ and titanium $\left(\mathrm{TiO}_{2}\right)$ content in some samples along with trace amounts of fluxing materials. The firing colors ranged from whitish/pinkish to brownish and reddish depending on the amounts of iron and titanium oxides present. Compared to the dark carbonaceous shales of cretaceous origin in this area, these clays are relatively free from carbonaceous matter, which makes the clays potentially suitable for pottery, refractory and brick productions.

Keywords : clay, kaolinitic, plasticity, carbonaceous, refractory, brick.

\section{Introduction}

Clay is an important and abundant raw material and has amazing variety of uses and properties that depend on the 
composition and other factors as enumerated by Grim (1968). These factors are clay mineral composition, non-clay mineral composition, presence of organic material, the type and amount of exchangeable ions and soluble salts, and texture. Clays are composed of certain groups of hydrous aluminum, magnesium, and iron silicates that may contain sodium, calcium, potassium and other ions. These silicates collectively make up the clay minerals and the major clay mineral groups are kaolins, smectites, illites, chlorites, and hormites. The specific clay minerals are identified by several techniques including X-ray diffraction (Brindley and Brown, 1980) ,differential thermal analysis ( Smothers and Chiang, 1966), electron microscopy ( Beutelspacher and Van der Marel, 1968 ), and infrared spectrometry (Van der Marel and Beutelspacher, 1976).

Clays have several industrial uses which include the manufacture of refractories, pottery/ceramic wares and structural units. They are also used as fillers or extenders in various products. The identification and quantification of the clay and non-clay minerals present in a clay material determines their uses and related industries. Each industrial process requires certain property specifications that must be met by either the raw or refined clay. The refining or beneficiation of clays is an expensive process and it becomes uneconomical if the composition and properties of the raw clay differs greatly from the desired specification. Most of the relevant industrial properties of the raw clay are dependent on the composition and the particle size distribution of the clay as well as the grain shape. All these factors control the plasticity of the clay which plays a very important role in its industrial application (Akpokodje, et. al, 1991) 
The Composition and Physical Properties of some Clays...

The mineralogical, geochemical and economic appraisal of some clay and shale deposits of South Western and North Eastern Nigeria have been discussed by Emofurieta et.al (1994) . Clays and shales occur abundantly in the sedimentary basin of South Eastern Nigeria ( Akpokodje, et. al,1991). Ntekim et.al (1999) reported on the compositional and industrial assessment of clay deposits of Itu in South Eastern Nigeria. From available information (Akpokodje, 1986, 1989, Akpokodje, et. al.1991; Ntekim et. al,1999 and Attah, et. al, 2001), only limited investigations have been carried out on the clays of South Eastern Nigeria, particularly Cross River State.

This paper reports the results of studies carried out on the composition and some physical properties of potential commercial clays deposited in parts of Cross River State, Nigeria.

\section{Methodology \\ Study area}

Representative clay samples were collected from 18 known clay deposits in Cross River State of Nigeria. (Fig.1).

\section{Sample preparation}

In each case, $20 \mathrm{~g}$ of clay sample was placed in a $600 \mathrm{ml}$ polyethylene centrifuge bottle and $500 \mathrm{ml}$ of distilled water was added, and allowed to hydrate for 24hrs. The suspensions were shaken thoroughly and then centrifuged for $6 \mathrm{~min}$. at $600 \mathrm{rpm}$ in a centrifuge. The supernatant liquid was then poured into $200 \mathrm{ml}$ polypropylene cups, frozen and then placed in a freeze drier until the ice was sublimated (Constanzo,2001) sealed containers before taking to the laboratory for analysis.

\section{Particle size determination}

Particle size determination was carried out by soaking the samples for $24 \mathrm{hrs}$ and sieving with a mechanical shaker using mesh sizes ranging from $14 \mathrm{~mm}$ to 75 micron. 


\section{Plasticity index}

Plasticity index was determined using Atterberg liquid and plastic limit equipments and was calculated as the difference between liquid and plastic limits. $\mathrm{pH}$ and loss-onignition (LOI) tests were carried out using standard methods.

\section{Analysis of samples}

The samples were saturated with $\mathrm{NH}_{4}{ }^{+}$prior to total elemental analysis, following the general procedure of Brindley and Ertem (1971). The procedure involved washing the sample three times with a solution of $1 \mathrm{M} \mathrm{NH}_{4} \mathrm{Cl}$ and then with $50 \%$ (V/V) mixture of ethanol and distilled water until the supernatant was free of $\mathrm{Cl}^{-}$by the $\mathrm{AgNO}_{3}$ method. The samples were oven dried overnight at $105^{\circ} \mathrm{C}$.

The elemental composition of the clays was determined following digestion with aqua regia and perchloric acid. The $\mathrm{Na}, \mathrm{K}$ and $\mathrm{Ca}$ contents were determined using Jenway Flame Emission photometer, PFP-7. All other elements, $\mathrm{Si}, \mathrm{Al}, \mathrm{Fe}, \mathrm{Mg}$ and $\mathrm{Ti}$ were determined using Atomic Absorption spectrophotometer (UNICAM 919). Three replicate analysis were averaged to obtain a single value.

Mineralogical studies were carried out using a Phillips $X$ - ray diffractometer model PW1710. All samples were randomly mounted and analyzed serially using $\mathrm{Cu}-\mathrm{ka}$ radiation at $45 \mathrm{kv}$ and $20 \mathrm{~mA}$. at the scan speed of $2^{\circ}$ per minute.

\section{Results and Discussion}

The particle size analysis of the clay samples are presented in Figure 2. On the basis of the clay percentages passing through the 75 micron sieve, Ekpokpa, Ediba, Akpet, Ikot Effanga I, Ikot Omin and Atan Okoyong clays appear to be the finest, with the clay from Abini being the coarsest. The 
The Composition and Physical Properties of some Clays...

other samples are between the two extremes. Apart from the Abini clay, the other clays are actually very fine, inorganic plastic clays. Table 1 showed the results of some physical properties of the various clay samples. The values of the plasticity index varied from $9-38 \%$, while the linear shrinkage values ranged from $8-18 \%$, with the higher figures corresponding to the more transportation clays of the tertiaryto recent environment.

From the results of the chemical composition of the clays as shown in Table 2, the highest silica $\left(\mathrm{SiO}_{2}\right)$ content $(>70 \%)$ was found in clay samples from Akpet I and Atan Okoyong, while clays from Ekpakpa, Betukwel and Nyanya also contained high amounts of silica ( $>60 \%$ ), with the lowest silica contents found in Bisu (47.20\%) and Ikot Effanga II (49\%) samples. The alumina $\left(\mathrm{Al}_{2} \mathrm{O}_{3}\right)$ contents of the clays ranged from $6-35 \%$. The highest alumina content of $35 \%$ was found in the Bisu clay with the Ikot Effanga I and II samples having values of $31.45 \%$ and $33.45 \%$ alumina content respectively, while lower values of $6.80 \%$ were obtained for clays from Nyanya and Atan Okoyong, and $6.96 \%$ for the Ediba clay. The iron $\left(\mathrm{Fe}_{2} \mathrm{O}_{3}\right)$ content which was generally high in all the samples ranged from $1.5-10.28 \%$, with the Abini clay having the highest (10.28\%) and considerable amount of titanium oxide $(2.62 \%)$ than allowed. The higher concentrations of iron oxides give rise to pinkish, brownish and reddish firing colors which are objectionable in paper and some ceramic industries. The high proportions of iron oxides $(>3 \%)$, in the clay deposites of Ovonum, Betkuwel, Nyanya, Ediba, Abani, AkpetI, Aguaguna, Ikot Omin, Ikot Effanga and Akpap Okoyong render them unsuitable for the paper and ceramic industries. However, they are suitable for brick and pottery productions. Although the other clays can be refined to reduce the iron and titanium oxides, to the desired levels for paper production, the process may be too expensive for 
industrial purposes. Substantial though variable amounts of flux materials such as $\mathrm{CaO}, \mathrm{MgO}, \mathrm{Na}_{2} \mathrm{O}, \mathrm{K}_{2} \mathrm{O}$ were also found in all the clay samples. Generally, clays contain low amounts of alkalis and magnesia. The slightly higher amount of lime $(\mathrm{CaO})$ in the sample from Nyanya (3\%), could be attributed to the presence of carbonates. $\mathrm{pH}$ values of the clay deposits vary from 4.4-9.4 with the more acidic varieties attributed to clays from tertiary- to- recent environment.

Figures 3-6 showed X-ray diffractograms for some selected clay samples. The dominant clay mineral found was kaolin with occasional illite and the main non-clay mineral as quartz. Apart from Ikot Effanga clay, which may be classified as fire clay by virtue of the high alumina and iron content, the rest of the clays may be classified as ball clays.

When compared to the dark, carbonaceous shales of Cretaceous origin in this area, these clays are relatively free from carbonaceous matter. Although the clay samples are of sedimentary origin, they seem to have gone through different amounts of transportation before deposition which does affect their physical properties such as plasticity index and shrinkage level. From the ceramic point of view (Worral, 1976; Hegab et.al 1984, Akpokodje et.al, 1991, Mermunt et.al, 2001, Attah et. al, 2001), the investigated clays can be considered as low alumina content with considerable amount of $\mathrm{Fe}_{2} \mathrm{O}_{3}$ and other impurity oxides and can be utilized in ceramic, refractory or brick industries. Ikot Omin and Ikot Effanga I clays could be further beneficiated to produce paper clays.

\section{Conclusion}

From the properties of the clays obtained, it can be concluded that the clays contain large amounts of silica, 
alumina, and iron with variable amounts of flux minerals and are principally kaolinitic with only occasional illite and quartz as the main contaminant. The high alumina clays are useful in the production of bricks while the low alumina clays could be applied in the production of ceramic and pottery wares.

\section{Acknowledgment}

LEA would like to thank M I Oden for providing the clay samples, the University of Uyo consultancy services for the use of Flame photometer and Atomic Absorption spectrophotometer, and H H Murray of Indiana University, USA for the X-ray diffractograms.

\section{Table 1: Some Physical Properties of the Clay Minerals}

\begin{tabular}{|l|l|l|l|}
\hline Sample location & $\begin{array}{l}\text { Plasticity Index } \\
(\%)\end{array}$ & $\%$ Shrinkage & Firing Color \\
\hline Ovonum & 21 & 13 & Pinkish \\
\hline Ikom & 16 & 14 & Whitish \\
\hline Ekpokpa & 9 & 16 & Whitish \\
\hline Adijinkpor & 23 & 15 & Brownish \\
\hline Bisu & 17 & 12 & Whitish \\
\hline Betukwell & 24 & 11 & Brownish \\
\hline Utugwang & 20 & 13 & Whitish \\
\hline Nyanya & 21 & 13 & Brownish \\
\hline Ediba & 19 & 14 & Brownish \\
\hline Abini & 13 & 8 & Reddish \\
\hline Akpet & 20 & 15 & Brownish \\
\hline Agwagune & 38 & 16 & Brownish \\
\hline Ikot Omin & 25 & 16 & Reddish \\
\hline Ikot Effanga I & 27 & 18 & Pinkish \\
\hline Ikot Effanga II & 29 & 15 & Pinkish \\
\hline Atan Okoyong & 31 & 18 & Whitish \\
\hline Akpap Okoyong & 23 & 14 & Brownish \\
\hline
\end{tabular}




\section{Table 2: Ph and Chemical Composition of the Clay Minerals (\%)}

\section{LOI : loss-on-ignition}

\begin{tabular}{|c|c|c|c|c|c|c|c|c|c|c|c|}
\hline $\begin{array}{l}\text { Sample } \\
\text { location }\end{array}$ & $\mathrm{SiO}_{2}$ & $\mathrm{Al}_{2} \mathrm{O}_{3}$ & $\begin{array}{l}\mathrm{Fe}_{2} \mathrm{O} \\
3\end{array}$ & $\mathrm{TiO}_{2}$ & $\mathrm{CaO}$ & $\mathrm{MgO}$ & $\mathrm{Na}_{2} \mathrm{O}$ & $\mathrm{K}_{2} \mathrm{O}$ & LOI & TOTAL & $\mathrm{pH}$ \\
\hline Ovonum & 51.25 & 24.50 & 3.35 & 0.89 & 1.19 & 1.67 & 1.02 & 1.03 & 15.55 & 100.45 & 4.5 \\
\hline Ikom & 51.25 & 30.01 & 2.46 & 0.74 & 1.23 & 0.45 & 2.01 & 0.24 & 11.00 & 99.39 & 4.8 \\
\hline Ekpokpa & 63.31 & 9.83 & 1.52 & 0.05 & 1.86 & 0.70 & 4.04 & 6.70 & 12.10 & 100.11 & 7.6 \\
\hline Adijikpor & 58.86 & 12.03 & 8.06 & 0.40 & 1.80 & 1.60 & 1.30 & 1.40 & 13.56 & 99.01 & 5.3 \\
\hline Bisu & 47.20 & 35.11 & 1.78 & 0.89 & 0.06 & 0.08 & 0.05 & 0.71 & 15.95 & 101.83 & 7.5 \\
\hline Betukwel & 62.39 & 9.92 & 6.41 & 0.60 & 2.59 & 0.77 & 4.42 & 0.96 & 11.10 & 99.16 & 7.4 \\
\hline $\begin{array}{l}\text { Utunwan } \\
\mathrm{g}\end{array}$ & 50.50 & 29.60 & 2.29 & 0.63 & 0.08 & 0.05 & 0.19 & 0.21 & 16.40 & 99.95 & 9.4 \\
\hline Nyanya & 60.00 & 6.80 & 6.86 & 0.35 & 3.00 & 2.25 & 2.01 & 2.35 & 16.67 & 100.29 & 8.1 \\
\hline Ediba & 60.00 & 6.96 & 6.82 & 0.07 & 2.16 & 1.72 & 1.60 & 2.20 & 18.80 & 100.33 & 4.7 \\
\hline Abini & 58.96 & 10.56 & $\begin{array}{l}10 . \\
28\end{array}$ & $\begin{array}{l}2.6 \\
2\end{array}$ & $\begin{array}{l}2.6 \\
3\end{array}$ & $\begin{array}{l}2.1 \\
0\end{array}$ & $\begin{array}{l}1.8 \\
6\end{array}$ & $\begin{array}{l}1.7 \\
8\end{array}$ & 10.00 & $\begin{array}{l}100.7 \\
9\end{array}$ & 5.0 \\
\hline Akpet & 71.60 & 12.90 & $\begin{array}{l}7.4 \\
3 \\
\end{array}$ & $\begin{array}{l}0.8 \\
1 \\
\end{array}$ & $\begin{array}{l}0.8 \\
3 \\
\end{array}$ & $\begin{array}{l}0.4 \\
7\end{array}$ & $\begin{array}{l}0.0 \\
5\end{array}$ & $\begin{array}{l}1.0 \\
5\end{array}$ & 4.60 & 99.74 & 7.3 \\
\hline $\begin{array}{l}\text { Aguagun } \\
\mathrm{e}\end{array}$ & 55.60 & 14.20 & 6.62 & 0.48 & 1.89 & 2.10 & 1.60 & 2.20 & 15.10 & 99.79 & 7.6 \\
\hline $\begin{array}{l}\text { Ikot } \\
\text { Omin }\end{array}$ & 61.82 & 9.94 & 9.12 & 0.98 & 2.39 & 1.68 & 1.46 & 0.96 & 11.09 & 99.44 & 4.4 \\
\hline $\begin{array}{l}\text { Ikot } \\
\text { Effanga I }\end{array}$ & 50.63 & 31.45 & 4.43 & 0.65 & 0.69 & 0.94 & 0.25 & 0.42 & 10.06 & 99.52 & 4.0 \\
\hline $\begin{array}{l}\text { Ikot } \\
\text { Effanga } \\
\text { II }\end{array}$ & 48.65 & 33.45 & 4.85 & 0.49 & 0.21 & 0.67 & 0.36 & 0.93 & 10.19 & 99.8 & 4.8 \\
\hline $\begin{array}{l}\text { Atan } \\
\text { Okoyong }\end{array}$ & 73.15 & 6.80 & 2.23 & 0.05 & 2.02 & 0.03 & 1.35 & 0.94 & 13.21 & 99.78 & 7.2 \\
\hline $\begin{array}{l}\text { Akpap } \\
\text { Okoyong }\end{array}$ & 57.34 & 9.89 & 7.20 & 0.07 & 2.70 & 2.24 & 2.00 & 2.13 & 16.31 & 99.88 & 4.4 \\
\hline
\end{tabular}


The Composition and Physical Properties of some Clays...

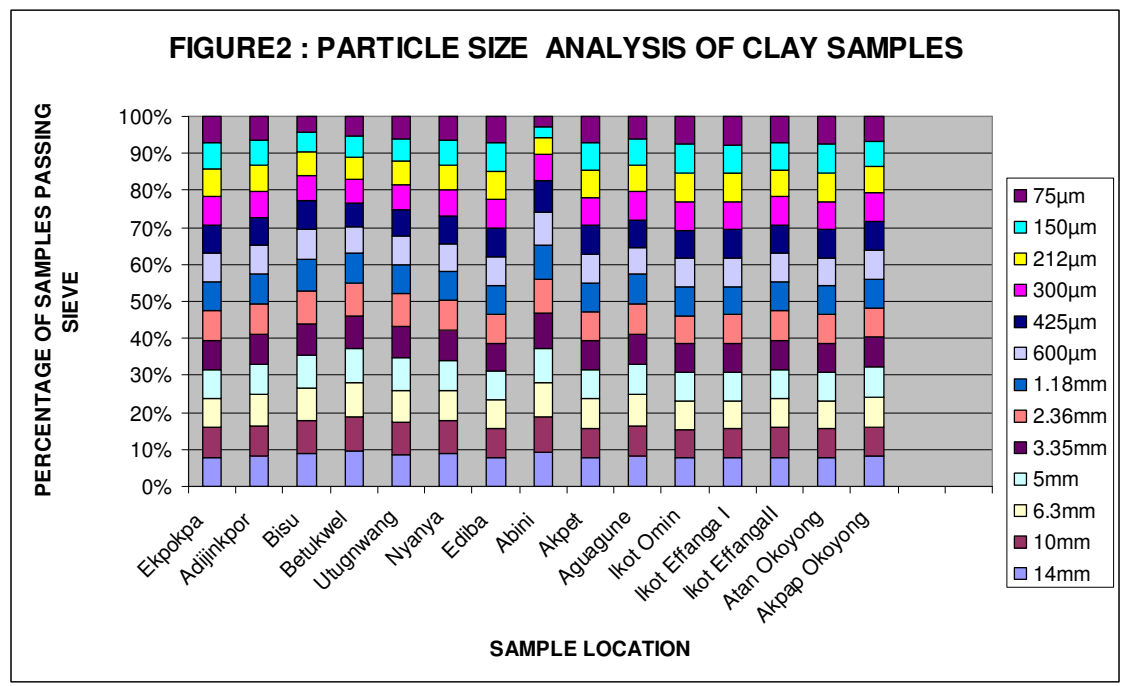

\section{References}

Grim, R. E. (1968): Clay mineralogy. 2nd Edition. McGrawHill, New York, 596p

Brindley, G. W. and Brown G. (1980): Crystal structures of clay minerals and their X-ray identification: Monograph 5,

Mineralogical 500, London, 495p

Smothens, W. J and Chiang, Y (1966): Handbook of

Differential Thermal Analysis: Chem. Pub. Co, New

York, 633p

Beutespacher, H, and Van Der Marel, H. W. C. (1968): Atlas of Infrared Spectroscopy of clay minerals and their admixtures, Elservier, Amsterdam, 333p

Van Der Marel, H. W. and Beutespacher, H (1976): Atlas of Infrared spectroscopy of clay minerals and their admixtures, Elservier, Amsterdam, 396p Akpokodje, E.G., Etu- Efeotor, J. O. and Olurufemi, B. N. (1991): The compositional and physical of some ceramic and pottery clays of South Eastern Nigeria, J. of Mining and Geology, vol.27 (1), 1-8 
Emofurieta, W. O; Ogundirim, T. O. and Imeokpai, E. G. (1994): Mineralogical, Geochemical and Economic appraisal of some clay and shale deposits of South Western and North Eastern Nigeria, J. of Mining and Geology, 30, 157-159

Ntekim, E. E.; Elueze, A. A. and Ekwere, S. J. (1999):

Compositional and industrial assessment of clay deposits

in Itu, S. E., Nigeria; Nig. J. of Min. Geo, vol 2, (1), 23-

Akpokodje, E. G. (1986): Engineering Geological

characteristics and classification of the superficial soils of the Niger Delta; Engineering Geology, 23,193-211 Akpokodje, E. G. (1989): Preliminary studies on the geotechnical characteristics of the Niger Delta subsoils;

Engineering Geology, 26, 247-259

Attah, L. E; Oden, M. I and Ibok, U. J. (2001): Brick forming properties of Odukpani clay deposits from physical, mechanical and mineralogical studies. West African J. of Research and Development in Education, vol. 8, (1), 93Constanzo, P.M (2001): Clay and clay minerals, 49,372 Brindley, G. W and Ertem, G (1971): Clay and clay minerals, 19,129

Worrall, W. E. (1976): Clay and ceramics Raw Materials. $2^{\text {nd }}$ Ed. Elservier Applied Science. 48-87 Hegab, O. A; Serry, M. A. and El-Banna (1984): Effect of composition of some Egyptian clays on their ceramic properties, Intercam, 33 (6), 31-33

Mermut, A. R.; Mermunt, A. R. and Cano, A. F. (2001):

Baseline studies of clay minerals society source clays: Chemical analysis of major elements; Clay and Clay Minerals, 49 (5), 381-386 